Reviu Akuntansi dan Bisnis Indonesia, Vol. 3 No. 2, Hlm: 139-148, Desember 2019

Website: http://journal.umy.ac.id/index.php/rab

\title{
Hubungan Corporate Governance dengan Market Power Perusahaan: Studi Pada Perusahaan Perbankan yang Terdaftar di Bursa Efek Indonesia Tahun 2013-2017
}

\author{
Kicky Feldareza, Rahmat Febrianto* \\ Program Studi Akuntansi Universitas Andalas \\ I N F O A R T I K E L \\ Kata Kunci: \\ Corporate Governance, \\ Self-Assessed Corporate \\ Governance rating, Market \\ Power, Net Interest Margin. \\ Jenis Artikel: \\ Penelitian Empiris \\ Correspondence: \\ febrianto.rahmat@gmail.com \\ A B S T R A K \\ Tujuan dari penelitian ini adalah untuk mengetahui hubungan market \\ power perusahaan dengan kualitas corporate governance pada perusahaan \\ perbankan yang terdaftar di Bursa Efek Indonesia tahun 2013-2017. \\ Sampel dipilih dengan kriteria tetapan dan diperoleh 140 sampel. Hasil \\ penelitian ini menunjukkan bahwa market power perusahaan untuk \\ peringkat self-assessment corporate governance yang lebih baik lebih tinggi \\ dibandingkan dengan market power perusahaan untuk peringkat self- \\ assessment corporate governance yang lebih rendah. Artinya, perusahaan \\ yang memiliki kualitas corporate governance yang berbeda, memiliki \\ kemampuan market power yang berbeda juga. Kualitas tata kelola \\ ditentukan sendiri oleh sampel perusahaan perbankan. Kelemahan dalam \\ penilaian mandiri tersebut menjadi kelemahan utama riset ini.
}

(C) 2019 RAB. Published by Universitas Muhammadiyah Yogyakarta

\section{PENDAHULUAN}

Tata kelola perusahaan yang baik (GCG) adalah sebuah kebutuhan yang nyata bagi perusahaan. Penerapan GCG dapat membantu perusahaan dalam menilai kinerja perusahaan dan dapat meningkatkan kepercayaan investor sehingga perusahaan dapat terus tumbuh menjadi lebih baik. Menurut Ketua Dewan Komisioner Otoritas Jasa Keuangan, Wimboh Santoso yang ditulis Primadhyta dalam berita CNN Indonesia (2017), penerapan good corporate governance di Indonesia saat ini relatif tertinggal dibandingkan negara-negara di kawasan ASEAN. Hal ini ditunjukkan dengan fakta bahwa hanya dua emiten dari Indonesia yang masuk dalam daftar 50 emiten terbaik dalam praktik GCG di ASEAN dalam ajang penganugerahan ASEAN Corporate Governance Awards 2015 yang diselenggarakan oleh ASEAN Capital Market Forum (ACMF) di Manila, Filipina. Kita masih tertinggal jauh dari Thailand yang mampu menempatkan 23 emiten, Filipina 11 emiten, Singapura 8 emiten dan Malaysia 6 emiten. Kedua emiten dari Indonesia tersebut yaitu PT Bank Danamon Tbk dan PT Bank CIMB Niaga Tbk.

Menurut Newel dan Wilson (2002), secara teoretis, praktik good corporate governance dapat meningkatkan nilai perusahaan, meningkatkan kinerja keuangan, mengurangi risiko yang mungkin dilakukan oleh dewan dengan keputusan-keputusan yang menguntungkan diri sendiri, dan secara umum meningkatkan kepercayaan investor. Masyitoh dan Hidayah (2018) telah melakukan penelitian terkait pengaruh penerapan good corporate governance terhadap kinerja perusahaan. Hasil penelitian menunjukkan bahwa ukuran dewan direksi berpengaruh positif signifikan secara statistis terhadap ROE, namun dua variabel lain yaitu kepemilikan publik dan kepemilikan manajerial tidak berpengaruh terhadap ROE perusahaan. Nizamullah et al. (2014) telah melakukan 
penelitian tentang pengaruh penerapan good corporate governance terhadap kinerja keuangan. Pengaruh penerapan GCG diukur dengan nilai komposit PBI No. 8/4/PBI/2006 sebagai variabel independen terhadap kinerja keuangan yang diukur dengan return on asset (ROA) sebagai variabel dependen. Hasil penelitian menunjukkan bahwa penerapan GCG yang diukur dengan nilai komposit PBI No. 8/4/PBI/2006 berpengaruh signifikan dan negatif secara statistis terhadap kinerja keuangan pada perusahaan perbankan nasional publik di Bursa Efek Indonesia yang diukur dengan return on assest $(\mathrm{ROA})$.

Kinerja perusahaan adalah ukuran efisiensi sosial yang didefinisikan oleh market power. Market power adalah kemampuan perusahaan untuk mempengaruhi harga pasar dan atau mengalahkan pesaing. Menurut Maudos dan Guevara (2004), analisis tentang market power dalam konteks industri perbankan menjadi sangat penting karena dapat menyebabkan tingginya biaya intermediasi keuangan dan rendahnya jumlah simpanan dan investasi, sehingga berdampak pada rendahnya pertumbuhan ekonomi. Di sisi lain, market power juga dapat berpengaruh positif tingginya profitabilitas perbankan yang berguna untuk menghadapi bermacam-bermacam risiko dan menyebabkan stabilitas sistem perbankan.

Dalam rangka meningkatkan kinerja bank, melindungi kepentingan pemangku kepentingan, dan meningkatkan kepatuhan terhadap peraturan perundang-undangan serta nilai etika yang berlaku umum pada industri perbankan, bank wajib melaksanakan kegiatan usaha dengan berpedoman pada prinsip tata kelola yang baik sebagaimana diatur dalam Peraturan Otoritas Jasa Keuangan Nomor 55/POJK.03/2016 tentang Penerapan Tata Kelola Bagi Bank Umum. Dalam POJK Nomor 55/POJK.03/2016 disebut kan bahwa tata kelola yang baik adalah suatu tata cara pengelolaan bank yang menerapkan prinsip-prinsip keterbukaan (transparency), akuntabilitas (accountability), pertanggungjawaban (responsibility), independensi (independency), dan kewajaran (fairness). Dalam rangka memastikan penerapan lima prinsip dasar tata kelola yang baik, bank harus melakukan penilaian sendiri (self-assessment) secara berkala yang paling sedikit meliputi 11 faktor penilaian penerapan tata kelola. Hasil dari penilaian ini berbentuk peringkat yang menunjukkan bagaimana penerapan pedoman serta pemenuhan kriteria yang telah dirancang Otoritas Jasa Keuangan oleh perusahaan.

Sejauh ini, penulis tidak menemukan adanya penelitian yang menunjukkan bagaimana hubungan corporate governance terhadap market power perusahaan di Indonesia. Oleh karena itu, penulis ingin melihat tingkat kepatuhan perbankan di Indonesia dalam menerapkan Peraturan Otoritas Jasa Keuangan dan mengetahui hubungan penerapan corporate governance dengan market power perusahaan karena belum ada penelitian di Indonesia terkait corporate governance dan market power perusahaan. Akan tetapi terdapat penelitian yang telah dilakukan di Taiwan oleh Chang et al. (2018) terkait corporate governance and product market power. Penelitian ini menyimpulkan bahwa corporate governance yang lebih baik memiliki pengaruh yang positif terhadap product market power perusahaan. Sebelumnya, La Porta et al. (2000) juga meneliti tentang investor protection and corporate governance. Mereka menyimpulkan bahwa corporate governance perlu di pasar negara berkembang. Mereka juga menyatakan bahwa perusahaan yang menerapkan corporate governance yang lebih baik dapat meningkatkan nilai perusahaan di industri non-kompetitif, perlindungan investor, dan kepatuhan dalam penegakan hukum.

\section{TINJAUAN LITERATUR DAN PERUMUSAN HIPOTESIS}

Pengertian Corporate Governance

Menurut Forum for Corporate Governance in Indonesia (FCGI) (2001), pengertian corporate governance adalah seperangkat peraturan yang mengatur hubungan antara pemegang saham, pengurus (pengelola) perusahaan, pihak kreditur, pemerintahan, karyawan serta para pemegang kepentingan internal dan eksternal lainnya sehubungan dengan hak-hak dan kewajiban mereka, atau dengan kata lain suatu sistem yang mengatur dan mengendalikan perusahaan. Tujuan 
corporate governance adalah untuk menciptakan nilai tambah bagi semua pihak pemegang kepentingan.

Menurut Organization for Economic Co-Operation and Development (OECD) (2005), pengertian corporate governance adalah sebagai sekumpulan hubungan antara pihak manajemen perusahaan, dewan dan pemegang saham, dan pihak lain yang mempunyai kepentingan dengan perusahaan. Corporate governance juga mensyaratkan adanya struktur perangkat untuk mencapai tujuan dan pengawasan atas kinerja. Good corporate governance dapat memberikan insentif yang baik bagi dewan dan manajemen untuk mencapai tujuan perusahaan. Tujuan tersebut merupakan kepentingan perusahaan dan pemegang saham serta harus memfasilitasi pemonitoran yang efektif, sehingga mendorong perusahaan untuk menggunakan sumber daya yang lebih efisien. Jadi dapat disimpulkan bahwa corporate governance adalah suatu sistem yang mengatur, mengelola, dan mengawasi proses pengendalian usaha yang berjalan secara berkesinambungan (sustainable) untuk meningkatkan nilai perusahaan, sekaligus sebagai bentuk perhatian kepada stakeholder, karyawan, kreditor dan masyarakat sekitar.

\section{Manfaat Corporate Governance}

Penerapan corporate governance banyak memberikan manfaat baik perusahaan maupun pihak lain yang mempunyai hubungan langsung dan tidak langsung dengan perusahaan. Menurut Forum for Corporate Governance in Indonesia (FCGI) (2001), manfaat dari penerapan good corporate governance adalah:

a. Meningkatkan kinerja perusahaan melalui terciptanya proses pengambilan keputusan yang lebih baik, meningkatkan efisiensi operasional perusahaan serta lebih meningkatkan pelayanan kepada stakeholders.

b. Mempermudah diperolehnya dana pembiayaan yang lebih murah (karena faktor kepercayaan) yang pada akhirnya akan meningkatkan corporate value.

c. Mengembalikan kepercayaan investor untuk menanamkan modalnya di Indonesia.

d. Pemegang saham akan merasa puas dengan kinerja perusahaan karena sekaligus akan meningkatkan shareholder's value dan deviden.

Prinsip-prinsip Corporate Governance

Dalam rangka meningkatkan kinerja perusahaannya, bank wajib melaksanakan kegiatan usaha dengan berpedoman pada prinsip tata kelola yang baik sebagaimana diatur dalam POJK Nomor 55/POJK.03/2016 tentang Penerapan Tata Kelola Bagi Bank Umum. Peraturan ini merupakan pengganti dari Peraturan Bank Indonesia (PBI) Nomor 8/4/PBI/2006 tentang Pelaksanaan Good Corporate Governance bagi Bank Umum yang diubah menjadi PBI Nomor 8/14/PBI/2006. Dalam POJK Nomor 55/POJK.03/2016 tentang Penerapan Tata Kelola bagi Bank Umum menyebutkan bahwa tata kelola yang baik adalah suatu tata cara pengelolaan bank yang menerapkan prinsip-prinsip keterbukaan (transparency), akuntabilitas (accountability), pertanggungjawaban (responsibility), independensi (independency), dan kewajaran (fairness).

Penjelasan lebih lanjut juga terdapat dalam Surat Edaran Otoritas Jasa Keuangan (SEOJK) Nomor 13/SEOJK.03/2017 tentang Penerapan Tata Kelola Bagi Bank Umum bahwa penerapan tata kelola pada industri perbankan harus senantiasa berlandaskan pada lima prinsip dasar tata kelola yang baik sebagai berikut: 
a. Transparansi (Transparency)

Keterbukaan dalam mengemukakan informasi yang material dan relevan serta keterbukaan dalam melaksanakan proses pengambilan keputusan.

b. Akuntabilitas (Accountability)

Kejelasan fungsi dan pelaksanaan pertanggungjawaban organ bank sehingga pengelolaannya berjalan secara efektif.

c. Pertanggungjawaban (Responsibility)

Kesesuaian pengelolaan bank dengan peraturan perundang-undangan dan prinsip pengelolaan bank yang sehat.

d. Independensi (Independency)

Pengelolaan bank secara profesional tanpa pengaruh atau tekanan dari pihak manapun.

e. Kewajaran (fairness)

Keadilan dan kesetaraan dalam memenuhi hak-hak pemangku kepentingan yang timbul berdasarkan perjanjian dan peraturan perundang-undangan.

Dalam rangka memastikan penerapan lima prinsip dasar tata kelola yang baik tersebut, bank harus melakukan penilaian sendiri (self-assessment) secara berkala yang paling sedikit meliputi 11 faktor penilaian penerapan tata kelola. Hasil dari penilaian ini berbentuk peringkat yang menunjukkan bagaimana penerapan pedoman yang telah dirancang OJK oleh perusahaan. Dengan penilaian self-assessment ini, maka dapat dilihat bagaimana penerapan corporate governance pada perusahaan tersebut. Faktor-faktor penilaian penerapan tata kelola perusahaan berdasarkan peraturan yang ditetapkan OJK yaitu:

a) Pelaksanaan tugas dan tanggung jawab direksi;

b) Pelaksanaan tugas dan tanggung jawab dewan komisaris;

c) Kelengkapan dan pelaksanaan tugas komite;

d) Penanganan benturan kepentingan;

e) Penerapan fungsi kepatuhan;

f) Penerapan fungsi audit intern;

g) Penerapan fungsi audit ekstern;

h) Penerapan manajemen risiko termasuk sistem pengendalian intern;

i) Penyediaan dana kepada pihak terkait (related party) dan penyediaan dana besar (large exposure);

j) Transparansi kondisi keuangan dan non-keuangan bank, laporan pelaksanaan tata kelola dan pelaporan internal; dan

k) Rencana strategis bank.

Di dalam lampiran 2 SEOJK nomor 13/SEOJK.03/2017, disebutkan bahwa terdapat lima peringkat penilaian penerapan tata kelola perusahaan perbankan yaitu:

- Peringkat 1: mencerminkan manajemen bank telah melakukan penerapan tata kelola yang secara umum sangat baik. Hal ini tercermin dari pemenuhan yang sangat memadai atas prinsip tata kelola. Dalam hal terdapat kelemahan penerapan prinsip tata kelola, secara umum kelemahan tersebut tidak signifikan dan dapat segera dilakukan perbaikan oleh manajemen bank.

- Peringkat 2: mencerminkan manajemen bank telah melakukan penerapan tata kelola yang secara umum baik. Hal ini tercermin dari pemenuhan yang memadai atas prinsip tata kelola. Dalam hal terdapat kelemahan penerapan prinsip tata kelola, secara umum kelemahan tersebut kurang signifikan dan dapat diselesaikan dengan tindakan normal oleh manajemen bank. 
- Peringkat 3: mencerminkan manajemen bank telah melakukan penerapan tata kelola yang secara umum cukup baik. Hal ini tercermin dari pemenuhan yang cukup memadai atas prinsip tata kelola. Dalam hal terdapat kelemahan penerapan prinsip tata kelola, secara umum kelemahan tersebut cukup signifikan dan memerlukan perhatian yang cukup dari manajemen bank.

- Peringkat 4: mencerminkan manajemen bank telah melakukan penerapan tata kelola yang secara umum kurang baik. Hal ini tercermin dari pemenuhan yang kurang memadai atas prinsip tata kelola. Terdapat kelemahan dalam penerapan prinsip tata kelola yang secara umum signifikan dan memerlukan perbaikan yang menyeluruh oleh manajemen bank.

- Peringkat 5: mencerminkan manajemen bank telah melakukan penerapan tata kelola yang secara umum tidak baik. Hal ini tercermin dari pemenuhan yang tidak memadai atas prinsip tata kelola. Terdapat kelemahan dalam penerapan prinsip tata kelola yang secara umum sangat signifikan dan sulit untuk diperbaiki oleh manajemen bank.

\section{Market Power dan Tata Kelola Perusahaan}

American Bar Association (2005) menyebutkan para ekonom mendefinisikan market power sebagai kemampuan perusahaan atau sekelompok perusahaan yang mempengaruhi pasar untuk mendapatkan keuntungan dengan cara menetapkan harga pada tingkat yang kompetitif dalam jangka waktu yang panjang. Berdasarkan definisi tersebut dapat disimpulkan bahwa perusahaan yang memiliki market power adalah perusahaan yang tetap mendapatkan keuntungan pada saat terjadi kenaikan harga pada tingkat berapapun, karena setiap perusahaan dapat menaikkan harga, namun tidak semua perusahaan mendapatkan keuntungan karena peningkatan harga tersebut.

Rasio net interst margin dapat digunakan sebagai acuan untuk menentukan strategi investasi bank dan investor. Rasio ini digunakan sebagai pengukur alternatif untuk variabel market power seperti yang digunakan oleh Maudos dan Guevara (2004). Mereka menyebutkan bahwa market power berpengaruh positif terhadap profitabilitas perbankan, dan kondisi persaingan pasar merupakan salah satu yang mempengaruhi interest margin perusahaan perbankan.

Dari uraian tersebut, hipotesis penelitian yang dikemukakan adalah sebagai berikut:

\section{$\boldsymbol{H}_{\boldsymbol{I}}$ : Market power perusahaan untuk peringkat self-assessment corporate governance yang lebih baik lebih tinggi dibandingkan dengan market power perusahaan untuk peringkat self- assessment corporate governance yang lebih rendah.}

\section{METODE PENELITIAN}

Sampel Penelitian

Sampel penelitian ini adalah seluruh perusahaan perbankan yang terdaftar di Bursa Efek Indonesia. Periode yang diambil adalah periode 2013-2017 dan sampel yang diambil adalah perusahaan yang memenuhi kriteria yang telah ditentukan peneliti. Kami menggunakan Peraturan OJK tahun 2016 sebagai acuan untuk tata kelola perbankan. Peraturan yang lebih awal yaitu Peraturan Bank Indonesia No. 8/4/PBI/2006 tentang Pelaksanaan Good Corporate Governance bagi Bank Umum yang diubah dengan dan Peraturan Bank Indonesia No. 8/14/PBI/2006 tidak kami gunakan sebagai acuan aturan GCG karena perubahan kedua aturan tersebut tidak signifikan.

Sampel yang digunakan dalam penelitian ini adalah perusahaan perbankan yang terdaftar di Bursa Efek Indonesia. Kriteria yang digunakan adalah sebagai berikut:

1. Perusahaan perbankan yang terdaftar di Bursa Efek Indonesia selama periode 2013-2017.

2. Perusahaan yang mempublikasikan laporan tahunan dalam website BEI atau website perusahaan selama periode pengamatan tahun 2013-2017. 
3. Perusahaan yang mencantumkan penilaian self-assessment penerapan corporate governance berdasarkan Peraturan Otoritas Jasa Keuangan Nomor 55/POJK.03/2016 tentang Penerapan Tata Kelola Bagi Bank Umum dan Surat Edaran Otoritas Jasa Keuangan Nomor 13/SEOJK.03/2017 tentang Penerapan Tata Kelola Bagi Bank Umum dalam laporan tahunan perusahaan tahun 2013-2017.

4. Perusahaan memiliki kelengkapan informasi yang dibutuhkan terkait dengan indikator-indikator perhitungan yang dijadikan variabel pada penelitian ini.

Berdasarkan kriteria tersebut, populasi dalam penelitian ini adalah sebanyak 43 perusahaan. Namun, ada pengurangan sebanyak 15 perusahaan yang dikeluarkan dari sampel dikarenakan tidak sesuai dengan kriteria yang telah ditetapkan untuk dijadikan sampel sehingga jumlah sampel yang digunakan dalam penelitian ini adalah sebanyak 28 perusahaan dan total sampel selama tahun penelitian adalah sebanyak 140 sampel.

Variabel Penelitian

Penelitian ini dilakukan untuk mengetahui hubungan market power perusahaan dengan kualitas corporate governance yang berbeda-beda pada perusahaan perbankan yang terdaftar di Bursa Efek Indonesia tahun 2013-2017. Variabel dependen dalam penelitian ini adalah market power. Market power didefinisi sebagai kemampuan perusahaan untuk mempengaruhi harga pasar dan/atau mengalahkan pesaing. Variabel dependen ini akan diukur dengan menggunakan net interest margin. Sesuai dengan Surat Edaran Bank Indonesia No.6/23/DPNP tanggal 31 Mei 2004, rasio net interest margin dirumuskan sebagai berikut:

$$
N I M=\frac{\text { Pendapatan Bunga Bersih }}{\text { Rata }- \text { rata Aktiva Produktif }} \mathrm{X} \text { 100\% }
$$

Pendapatan bunga bersih merupakan hasil dari pendapatan bunga dikurangi dengan beban bunga. Aktiva produktif yang dimaksud adalah rata-rata aktiva produktif yang digunakan. Dalam penelitian ini kami menggunakan variabel independen yaitu corporate governance. Pada penelitian ini, variabel independen corporate governance akan diukur dengan penilaian self-assessment penerapan corporate governance berdasarkan Peraturan Otoritas Jasa Keuangan Nomor 55/POJK.03/2016 tentang Penerapan Tata Kelola Bagi Bank Umum dan Surat Edaran Otoritas Jasa Keuangan Nomor 13/SEOJK.03/2017 tentang Penerapan Tata Kelola Bagi Bank Umum dengan menggunakan pengukuran peringkat self-assesment yaitu:

- Jika perusahaan diberi peringkat 1, maka memperoleh nilai sangat baik.

- Jika perusahaan diberi peringkat 2, maka memperoleh nilai baik.

- Jika perusahaan diberi peringkat 3, maka memperoleh nilai cukup baik.

- Jika perusahaan diberi peringkat 4, maka memperoleh nilai kurang baik.

- Jika perusahaan diberi peringkat 5, maka memperoleh nilai tidak baik.

Pengujian Hipotesis

Teknik analisis data dalam penelitian ini menggunakan model regresi berganda. Persamaan regresi yang digunakan adalah sebagai berikut:

$$
\mathbf{N I M}=\alpha+\beta_{1}\left(\mathbf{S A} \_\mathbf{B}\right)+\beta_{2}\left(\mathbf{S A} \_\mathbf{C B}\right)+\beta_{\mathbf{3}}\left(\mathbf{S A} \_\mathbf{K B}\right)+\mathbf{e}
$$

Keterangan :

$\begin{array}{ll}\mathrm{NIM} & =\text { net interest margin }(\mathrm{NIM}) \\ \alpha & =\text { konstanta }\end{array}$ 
SA_B = bernilai 1 jika peringkat self-assessment baik, 0 jika lainnya.

SA_CB = bernilai 1 jika peringkat self-assessment cukup baik, 0 jika lainnya.

SA_KB = bernilai 1 jika peringkat self-assessment kurang baik, 0 jika lainnya.

e $\quad=$ error

Statistik Deskriptif

Tabel 1 Statistik Deskriptif

\begin{tabular}{lcccccc}
\hline & Amatan & Minimum & Maksimum & Rata-rata & Simpangan Baku & Frekuensi \\
\hline NIM & 140 & 0,0024 & 0,1304 & 0,055443 & 0,0217910 & N/A \\
SA Sangat Baik & 140 & N/A & N/A & N/A & 0,301 & 14 \\
SA Baik & 140 & N/A & N/A & N/A & 0,407 & 111 \\
SA Cukup Baik & 140 & N/A & N/A & N/A & 0,281 & 12 \\
SA Kurang Baik & 140 & N/A & N/A & N/A & 0,145 & 3 \\
Valid N (listwise) & & & & 140 & & \\
\hline
\end{tabular}

\section{HASIL DAN PEMBAHASAN}

Analisis Regresi Linear Berganda

Tabel 6 Model Regresi Linear Berganda

\begin{tabular}{lccc}
\hline \multicolumn{1}{c}{ Variabel } & Koefisien regresi & $\mathbf{t}$ & Sig. \\
\hline (Constant) & 0,063 & 11,251 & 0,000 \\
SA Baik & $-0,006$ & $-1,001$ & 0,318 \\
SA Cukup Baik & $-0,023$ & $-2,813$ & 0,006 \\
SA Kurang Baik & $-0,036$ & $-2,718$ & 0,007 \\
F & & & 0,003 \\
Adj $\mathbf{R}^{2}$ & & 0,078 & \\
\hline
\end{tabular}

Berdasarkan tabel di atas, didapatkan koefisien regresi sebagai berikut:

$$
\mathrm{NIM}=0,063-0,006 \mathrm{SA} B \mathrm{~B}-0,023 \mathrm{SA} \_\mathrm{CB}-0,036 \mathrm{SA} \mathbf{K B}+\mathrm{e}
$$

Hasil pengujian tersebut memberikan indikasi sebagai berikut. Pertama, untuk perusahaan dengan kategori self-assessment "Baik", NIM perusahaan dengan kualitas GCG "Baik" lebih rendah 0,006 lebih rendah dibandingkan dengan NIM sampel yang kategori "Sangat Baik" namun perbedaannya tidak signifikan secara statistis. Artinya, kedua kelompok sampel perusahaan tidak memiliki perbedaan market power secara statistis. Kedua, untuk perusahaan dengan kategori selfassessment "Cukup Baik", NIM perusahaan dengan self-assessment "Sangat Baik" lebih tinggi 0,023 dari sampel yang nilai self-assessment "Cukup Baik" dan perbedaannya signifikan secara statistis. Artinya, market power kedua kelompok sampel perusahaan tidaklah sama. Ketiga, untuk perusahaan dengan kategori self-assessment "Kurang Baik", NIM sampel perusahaan dengan kategori "Sangat Baik" 0,036 lebih tinggi daripada sampel dengan kategori self-assessment "Kurang Baik" dan perbedaan kedua kelompok ini signifikan secara statistik.

Secara umum bisa disimpulkan bahwa perusahaan dengan kategori GCG lebih baik memiliki market power yang lebih tinggi dibandingkan dengan perusahaan dengan kategori GCG di bawahnya. Hasil pengujian mengindikasikan bahwa semakin jauh jarak market power kedua kelompoknya, makin signifikan perbedaan mereka secara statistis. 


\section{KESIMPULAN}

Penelitian ini bertujuan untuk mengetahui market power perusahaan dengan kualitas corporate governance yang berbeda-beda. Berdasarkan hasil penelitian, dapat disimpulkan bahwa market power perusahaan untuk peringkat self-assessment corporate governance yang lebih baik lebih tinggi dibandingkan dengan market power perusahaan untuk peringkat self-assessment corporate governance yang lebih rendah. Artinya, perusahaan yang memiliki kualitas corporate governance yang berbeda, memiliki kemampuan market power yang berbeda juga. Simpulan ini cukup kokoh mengingat bahwa bank-bank dengan NIM yang tinggi adalah juga bank dengan hasil penilain tata kelola yang juga lebih baik. Dapat dilihat pada lampiran data peringkat self-assessment perusahaan perbankan, seperti pada Bank Central Asia Tbk diberi peringkat 1 untuk tahun 20132017 yang berarti penerapan corporate governance Bank Central Asia Tbk sangat baik. Nilai NIM Bank Central Asia Tbk juga cukup tinggi sebesar 0,062 untuk tahun 2013. Sementera itu, Bank J Trust Indonesia Tbk untuk tahun 2013 dan 2014 diberi peringkat 4 yang berarti penerapan corporate governance Bank J Trust Indonesia Tbk kurang baik. Nilai NIM Bank J Trust Indonesia juga cukup rendah yaitu sebesar 0,0167 untuk tahun 2013.

\section{LAMPIRAN}

Lampiran 1

Daftar Sampel Perusahaan Perbankan Tahun 2013-2017

\begin{tabular}{ccl}
\hline No & Kode & \multicolumn{1}{c}{ Nama Perusahaan } \\
\hline 1 & AGRO & Bank Rakyat Indonesia Agro Niaga Tbk \\
2 & ARTO & Bank Artos Indonesia Tbk \\
3 & BBCA & Bank Central Asia Tbk \\
4 & BBKP & Bank Bukopin Tbk \\
5 & BBNI & Bank Negara Indonesia (Persero) Tbk \\
6 & BBNP & Bank Nusantara Parahyangan Tbk \\
7 & BBRI & Bank Rakyat Indonesia (Persero) Tbk \\
8 & BBYB & Bank Yudha Bhakti Tbk \\
9 & BCIC & Bank T Trust Indonesia Tbk \\
10 & BDMN & Bank Danamon Indonesia Tbk \\
11 & BEKS & Bank Pembangunan Daerah Banten Tbk \\
12 & BJBR & Bank Jabar Banten Tbk \\
13 & BJTM & Bank Pembangunan Daerah Jawa Timur Tbk \\
14 & BMAS & Bank Maspion Indonesia Tbk \\
15 & BMRI & Bank Mandiri (Persero) Tbk \\
16 & BNBA & Bank Bumi Arta Tbk \\
17 & BNGA & Bank CIMB Niaga Tbk \\
18 & BNII & Bank Maybank Indonesia Tbk \\
19 & BNLI & Bank Permata Tbk \\
20 & BSIM & Bank Sinar Mas Tbk \\
21 & BTPN & Bank Tabungan Pensiunan Nasional Tbk \\
22 & BVIC & Bank Victoria International Tbk \\
23 & INPC & Bank Artha Graha International Tbk \\
24 & MCOR & Bank China Construction Bank Ind. Tbk \\
25 & MEGA & Bank Mega Tbk \\
26 & NISP & Bank OCBC NISP Tbk \\
27 & NOBU & Bank Nationalnobu Tbk \\
28 & PNBN & Bank Pan Indonesia Tbk \\
\hline & &
\end{tabular}


Lampiran 2

Peringkat Self-Assessment

\begin{tabular}{|c|c|c|c|c|c|c|c|}
\hline \multirow{2}{*}{ No } & \multirow{2}{*}{ Kode } & \multirow{2}{*}{ Nama Perusahaan } & \multicolumn{5}{|c|}{ Peringkat Self-Assessment } \\
\hline & & & 2013 & 2014 & 2015 & 2016 & 2017 \\
\hline 1 & AGRO & Bank Rakyat Indonesia Agro Niaga Tbk & 2 & 2 & 2 & 2 & 2 \\
\hline 2 & ARTO & Bank Artos Indonesia Tbk & 2 & 3 & 3 & 3 & 3 \\
\hline 3 & BBCA & Bank Central Asia Tbk & 1 & 1 & 1 & 1 & 1 \\
\hline 4 & BBKP & Bank Bukopin Tbk & 2 & 2 & 2 & 2 & 2 \\
\hline 5 & BBNI & Bank Negara Indonesia (Persero) Tbk & 2 & 2 & 2 & 2 & 2 \\
\hline 6 & BBNP & Bank Nusantara Parahyangan Tbk & 2 & 2 & 2 & 2 & 2 \\
\hline 7 & BBRI & Bank Rakyat Indonesia (Persero) Tbk & 1 & 1 & 1 & 2 & 2 \\
\hline 8 & BBYB & Bank Yudha Bhakti Tbk & 2 & 2 & 2 & 2 & 3 \\
\hline 9 & $\mathrm{BCIC}$ & Bank J Trust Indonesia Tbk & 4 & 4 & 3 & 3 & 2 \\
\hline 10 & BDMN & Bank Danamon Indonesia Tbk & 2 & 2 & 2 & 2 & 2 \\
\hline 11 & BEKS & Bank Pembangunan Daerah Banten Tbk & 2 & 2 & 4 & 3 & 3 \\
\hline 12 & BJBR & Bank Jabar Banten Tbk & 2 & 2 & 2 & 2 & 2 \\
\hline 13 & BJTM & Bank Pembangunan Daerah Jawa Timur Tbk & 2 & 2 & 2 & 2 & 2 \\
\hline 14 & BMAS & Bank Maspion Indonesia Tbk & 2 & 2 & 2 & 2 & 2 \\
\hline 15 & BMRI & Bank Mandiri (Persero) Tbk & 1 & 2 & 2 & 1 & 1 \\
\hline 16 & BNBA & Bank Bumi Arta Tbk & 2 & 2 & 2 & 2 & 2 \\
\hline 17 & BNGA & Bank CIMB Niaga Tbk & 2 & 2 & 2 & 2 & 2 \\
\hline 18 & BNII & Bank Maybank Indonesia Tbk & 1 & 2 & 2 & 2 & 2 \\
\hline 19 & BNLI & Bank Permata Tbk & 2 & 2 & 2 & 3 & 2 \\
\hline 20 & BSIM & Bank Sinar Mas Tbk & 2 & 2 & 2 & 2 & 2 \\
\hline 21 & BTPN & Bank Tabungan Pensiunan Nasional Tbk & 2 & 2 & 2 & 2 & 2 \\
\hline 22 & BVIC & Bank Victoria International Tbk & 2 & 2 & 2 & 2 & 2 \\
\hline 23 & INPC & Bank Artha Graha International Tbk & 2 & 2 & 2 & 2 & 2 \\
\hline 24 & MCOR & Bank China Construction Bank Ind. Tbk & 2 & 2 & 2 & 2 & 3 \\
\hline 25 & MEGA & Bank Mega Tbk & 2 & 2 & 2 & 2 & 2 \\
\hline 26 & NISP & Bank OCBC NISP Tbk & 2 & 2 & 2 & 2 & 1 \\
\hline 27 & NOBU & Bank Nationalnobu Tbk & 1 & 3 & 2 & 2 & 2 \\
\hline 28 & PNBN & Bank Pan Indonesia Tbk & 2 & 2 & 2 & 2 & 2 \\
\hline
\end{tabular}

Lampiran 3

Net interest margin sampel

\begin{tabular}{cclccccc}
\hline \multirow{2}{*}{ No } & \multirow{2}{*}{ Kode } & \multicolumn{1}{c}{ Nama Perusahaan } & \multicolumn{5}{c}{ Net Interest Margin (NIM) } \\
& & & 2013 & 2014 & 2015 & 2016 & 2017 \\
\hline 1 & AGRO & Bank Rakyat Indonesia Agro Niaga Tbk & 0.0531 & 0.0462 & 0.0477 & 0.0435 & 0.0376 \\
2 & ARTO & Bank Artos Indonesia Tbk & 0.0675 & 0.0469 & 0.0534 & 0.0548 & 0.0481 \\
3 & BBCA & Bank Central Asia Tbk & 0.062 & 0.065 & 0.067 & 0.068 & 0.062 \\
4 & BBKP & Bank Bukopin Tbk & 0.0382 & 0.037 & 0.0358 & 0.0388 & 0.0289 \\
5 & BBNI & Bank Negara Indonesia (Persero) Tbk & 0.061 & 0.062 & 0.064 & 0.062 & 0.055 \\
6 & BBNP & Bank Nusantara Parahyangan Tbk & 0.0516 & 0.0469 & 0.0518 & 0.0613 & 0.0612 \\
7 & BBRI & Bank Rakyat Indonesia (Persero) Tbk & 0.0855 & 0.0851 & 0.0813 & 0.0827 & 0.0793 \\
8 & BBYB & Bank Yudha Bhakti Tbk & 0.0574 & 0.0538 & 0.0612 & 0.0696 & 0.0687 \\
9 & BCIC & Bank J Trust Indonesia Tbk & 0.0167 & 0.0024 & 0.0093 & 0.0226 & 0.0241 \\
10 & BDMN & Bank Danamon Indonesia Tbk & 0.096 & 0.084 & 0.082 & 0.089 & 0.093 \\
11 & BEKS & Bank Pembangunan Daerah Banten Tbk & 0.1304 & 0.0965 & 0.0611 & 0.0193 & 0.0307 \\
12 & BJBR & Bank Jabar Banten Tbk & 0.0796 & 0.0679 & 0.0632 & 0.074 & 0.0676 \\
13 & BJTM & Bank Pembangunan Daerah Jawa Timur & 0.0714 & 0.069 & 0.0641 & 0.0694 & 0.0668 \\
& & Tbk & 0.0507 & 0.0493 & 0.0442 & 0.0528 & 0.0495 \\
14 & BMAS & Bank Maspion Indonesia Tbk & 0.0568 & 0.0594 & 0.059 & 0.0629 & 0.0563 \\
15 & BMRI & Bank Mandiri (Persero) Tbk & 0.0661 & 0.0581 & 0.0549 & 0.0474 & 0.0481 \\
16 & BNBA & Bank Bumi Arta Tbk & 0.0534 & 0.0536 & 0.0521 & 0.0564 & 0.056 \\
17 & BNGA & Bank CIMB Niaga Tbk & 0.052 & 0.0476 & 0.0484 & 0.0461 & 0.0517 \\
18 & BNII & Bank Maybank Indonesia Tbk & 0.042 & 0.036 & 0.04 & 0.039 & 0.04 \\
19 & BNLI & Bank Permata Tbk & 0.0523 & 0.0587 & 0.0577 & 0.0644 & 0.0646 \\
20 & BSIM & Bank Sinar Mas Tbk & 0.127 & 0.114 & 0.113 & 0.12 & 0.116 \\
21 & BTPN & Bank Tabungan Pensiunan Nasional Tbk & 0.0233 & 0.0188 & 0.0208 & 0.0153 & 0.0213 \\
22 & BVIC & Bank Victoria International Tbk & 0.0531 & 0.0475 & 0.0456 & 0.0465 & 0.0515 \\
23 & INPC & Bank Artha Graha International Tbk & 0.0487 & 0.0376 & 0.0444 & 0.0448 & 0.0469 \\
24 & MCOR & Bank China Construction Bank Ind. Tbk & 0.045 \\
\hline
\end{tabular}




\begin{tabular}{cclccccc}
\hline 25 & MEGA & Bank Mega Tbk & 0.0538 & 0.0527 & 0.0604 & 0.0701 & 0.058 \\
26 & NISP & Bank OCBC NISP Tbk & 0.0411 & 0.0415 & 0.0407 & 0.0462 & 0.0447 \\
27 & NOBU & Bank Nationalnobu Tbk & 0.0322 & 0.0374 & 0.0389 & 0.0431 & 0.0422 \\
28 & PNBN & Bank Pan Indonesia Tbk & 0.0409 & 0.0383 & 0.0461 & 0.0503 & 0.0468 \\
\hline
\end{tabular}

\section{DAFTAR PUSTAKA}

American Bar Association (ABA). (2005). Market Power Handbook: Competition Law and Economic Foundations, USA: ABA Publishing, hal. 1 -2.

Chang, C., Chen, S., Farmania, A., Tsai, F., \& Wu, P. (2018). Corporate Governance and Product Market Power: Evidence From Taiwan. The International Journal of Business and Finance Research. 12, (1).

Forum for Corporate Governance Indonesia (FCGI). (2001). Corporate Governance: Tata Kelola Perusahaan. Edisi Ketiga, Jakarta.

La Porta, R., Lopez-de-Silanes, F., Sheifer, A., \& Vishny, R. (2000). Investor Protection and Corporate Governance. Journal of Financial Economics, 58, 3-27.

Masyitoh, N. S., \& Hidayah, N. (2018). Pengaruh Penerapan Good Corporate Governance terhadap Kinerja Perusahaan (Studi Empirik pada Perusahaan Perbankan di BEI tahun 2014-2016). Jurnal Tekun, 1(1)

Maudos, J. \& de Guevara, J. F. (2004). Factor Explaining the Interest Margin in the Banking Sector of the European Union. Journal of Banking and Finance :Universitat de Valencia dan Istituto Valanciano de Investigaciones Economicas Spain.

Newel, R., \& Wilson, G. (2002). A Premium for Good Governance. The McKinsey Quarterly, Number 3.

Nizamullah, D., \& Abdullah, S. (2014). Pengaruh Penerapan Good Corporate Governance terhadap Kinerja Keuangan (Studi Empiris Pada Perusahaan Perbankan yang Terdaftar di Bursa Efek Indonesia 2010-2012). Jurnal Akuntansi Program Pascasarjana Universitas Syiah Kuala.

Organization for Economic Co-Operation and Develpoment (OECD). (2005). Corporate Governance Definition. Diakses dari: https://stats.oecd.org/glossary/detail.asp?ID=6678, diakses pada tanggal 4 Juli 2019 pukul 19.17 WIB.

Otoritas Jasa Keuangan. (2016). Peraturan Otoritas Jasa Keuangan Nomor 55/POJK.03/2016 tentang Penerapan Tata Kelola Bagi Bank Umum tanggal 7 Desember 2016.

Otoritas Jasa Keuangan. (2017). Surat Edaran Otoritas Jasa Keuangan Nomor 13/SEOJK.03/2017 tentang Penerapan Tata Kelola Bagi Bank Umum tanggal 17 Maret 2017.

Primadhyta, Safyara. (2017). OJK: Praktik GCG Perusahaan Indonesia Masih Tertinggal. Diakses dari: https://www.cnnindonesia.com/ekonomi/20170920070153-78-242846/ojk-praktik-gcgperusahaan-indonesia-masih-tertinggal, diakses pada tanggal 28 Mei 2019 pukul 06.43 WIB. 